\title{
The effects of visual contact and aggressor identification on interpersonal aggression
}

\author{
LOUIS A. PENNER and HAROLD L. HAWKINS \\ University of South Florida, Tampa, Fla. 33620
}

Groups of four Ss were ordered by the $E$ to respond in a simple reaction time (RT) task in a way which (allegedly) would lead to the delivery of painful shock to a human "victim." It was found that compliance with these orders declined under conditions where the victim was given the specific identity of the potential harmer. However, compliance was not directly influenced by whether or not the victim and potential harmer were in visual contact.

Laboratory studies of aggression have tended to focus on an individual's willingness to harm another individual as a function of some internal motive state such as anger or frustration. While of considerable scientific and social value, this approach neglects the fact that many acts of aggression are committed on command and in the apparent absence of either frustration or anger, e.g., as is often true under conditions of war. Some of the most notable research on this latter form of aggression has been reported by Milgram (1965). A major finding of the Milgram studies was that situational variables are of critical importance in determining the extent to which a $\mathrm{S}$ will comply with orders to aggress. Chief among these variables is the physical separation, or "psychological distance," between S and the "victim." Thus, a marked decline in S's compliance with instructions to harm was observed by Milgram when $S$ was in the same room with the victim, enabling the two to directly view one another.

The present study was designed to explicate further the aggression-suppressing effect of visual contact between the harmer and his victim. Two alternative explanations of this effect were examined. The first relates to the visual pain cues provided to the aggressor by the victim. The potential importance of such cues (and of the emphatic response to which they presumably give rise) in determining interpersonal aggressiveness has been suggested by Milgram (1965) and by Baron (1971). In support of this argument, Baron found that increases in the saliance of the facial pain cues emitted by the victim in study on aggression compliance led to declines in the magnitude of the harmer's aggressive response. A second possible explanation of the effect of visual contact relates to the fact that, in the Milgram study, not only could the aggressor see his victim, but also the victim could see the aggressor. Thus, the aggressor was specifically and immediately identifiable by the victim as his harmer. The victim's ability to identify specifically his aggressor might, on the basis of prior social learning, heighten the aggressor's fear of retaliation and in this way lead to an inhibition of the aggressive response (Milgram, 1965; Bandura \& Walters, 1963).

These two interpretations were evaluated comparatively in a social conflict situation composed of a "victim" and four Ss. Prior to each trial of the experiment, each $\mathrm{S}$ was informed that she was either a harmer or a saver. A trial was initiated by the onset of a stimulus light to which all Ss were instructed to respond quickly (Donder's type-a reaction). The Ss were instructed further that if the individual designated the harmer was fastest to respond on a given trial, the victim would receive a painful shock. If, however, a saver was faster, then no shock would be administered. The Ss were explicitly ordered to respond as quickly as possible on all trials regardless of whether they were a harmer or saver. The magnitude of the aggressive response for each $\mathrm{S}$ was defined in terms of the average difference in reaction time (RT) between trials on which she was designated as the harmer relative to those on which she was designated the saver. Thus, resistence to instructions to harm (suppression of the aggressive response) was indexed by increases in latency on harming trials. Conversely, compliance with instructions to harm was defined in terms of the degree of adherence to the instruction to respond as rapidly as possible on both saving and harming trials. DESIGN

A randomized blocks design, which contained one between-S and two within-S variables, was used. The between-S variable involved whether or not the victim and Ss were visually accessible to one another (visual contact condition). One within-S variable involved whether or not the fastest $S$ to respond on a given trial was objectively identified for the victim (feedback condition). The other within-S variable involved whether or not $S$ was informed prior to a trial that she would be a harmer or a saver (response condition). Blocking was based on S's performance on a simple RT task administered about 1 week prior to the experimental session.

$$
\text { SUBJECTS }
$$

Thirty-two female undergraduates enrolled in introductory psychology at the University of South Florida participated in the experiment in exchange for course credit.

\section{APPARATUS}

The apparatus consisted of four Standard electric timers, four display-response panels, and a pair of finger electrodes connected to a simulated shock generator. Each display-response panel was located in one of four separate booths, all of which faced a single "victim" booth at a distance of approximately $4 \mathrm{ft}$. A display-response panel, visible only to the $S$ seated directly in front of it, contained four features: (1) a rear-illuminated translucent plastic display board which provided information to $S$ as to the conditions under which she would be responding, (2) four lights located below the display board which served to inform $S$ as to whether she would be a harmer or a saver on a given trial, (3) a RT stimulus light, and (4) a RT response button.

\section{PROCEDURE}

The experiment was represented to the five individuals (four Ss and a confederate) appearing for each experimental session as an investigation of human judgment under conditions of stress. The person whose judgments were to be evaluated was to be chosen by a drawing of lots among the five people present. In fact, this drawing was prearranged so that the confederate was always selected as the judge. The confederate was seated in the victim booth, the four Ss were seated across from her, and recorded instructions were presented. The instructions stated that the victim's task was to judge which of the four Ss was the fastest to respond on each trial of a simple RT task. The Ss were told that prior to each trial, one of them would be designated as "harmer" and the three others as "savers." These designations were communicated to Ss by means of the array of four lights located on each display-response panel below the translucent display board. When the light corresponding to a given S's position was illuminated, that $S$ became the harmer. Otherwise, she was a saver. The Ss were told further that if the harmer was fastest to respond on the $R T$ trial, the victim would receive a painful shock. Conversely, if a saver were fastest, 
Table 1

Arithmetic Mean Reaction Time (in Seconds) as a Function of Response Condition Visual Contact, and Harmer Identification. The values appearing in parentheses are SDs.

\begin{tabular}{|c|c|c|c|c|}
\hline & \multicolumn{2}{|c|}{ Visual Contact } & \multicolumn{2}{|c|}{ No Visual Contact } \\
\hline & $\begin{array}{c}\text { Harmer } \\
\text { Identified }\end{array}$ & $\begin{array}{l}\text { Harmer Not } \\
\text { Identified }\end{array}$ & $\begin{array}{c}\text { Harmer } \\
\text { Identified }\end{array}$ & $\begin{array}{l}\text { Harmer Not } \\
\text { Identified }\end{array}$ \\
\hline Saving Trials & $\begin{array}{c}.237 \\
(.023)\end{array}$ & $\begin{array}{c}.233 \\
(.018)\end{array}$ & $\begin{array}{c}.227 \\
(.020)\end{array}$ & $\begin{array}{c}.215 \\
(.017)\end{array}$ \\
\hline Harming Trials & $\begin{array}{c}.532 \\
(.132)\end{array}$ & $\begin{array}{c}.314 \\
(.050)\end{array}$ & $\begin{array}{c}.368 \\
(.076)\end{array}$ & $\begin{array}{l}.317 \\
(.052)\end{array}$ \\
\hline
\end{tabular}

then no shock would be administered. It was further emphasized that regardless of whether one was designated as harmer or saver, she was to respond as quickly as possible on all trials. The stated rationale for using shock in this study was that the $E$ specifically wished to investigate the effects of shock-induced stress on the victim's judgmental accuracy.

Following these general instructions, Ss received more specific information regarding the alleged objectives of the experiment. The precise nature of this information depended on whether a group was tested under conditions of visual contact or of no visual contact.

Visual Contact Condition

The Ss were informed that the victim's judgmental performance would be evaluated under two separate conditions of feedback. On objective feedback trials, a light corresponding to the fastest $S$ would go on in the victim's booth .5 sec prior to the three remaining lights. Thus, when the victim was "shocked," she could identify her harmer objectively by simply observing which of the four $S$ lights illuminated first. On no objective feedback trials, the victim was given no objective information as to the identity of the fastest S. The Ss were told that judgments would be evaluated under these two feedback conditions in order to determine whether the victim's accuracy on no-feedback trials would be facilitated by information which would be obtained on feedback trials. Messages appearing on the translucent plastic display board informed Ss of the feedback condition under which the victim would be responding on each trial.

No Visual Contact Condition

The procedures, conditions of feedback, and instructions were identical to those under the visual contact condition except that a view-obstructing barrier was placed between the victim and the Ss. Pilot work showed that this barrier, which prevented Ss from seeing the upper, but not the lower, half of the victim's body, did not impede S's ability to determine when the victim had been "shocked."
Each group of four Ss was tested in counterbalanced order on a total of six 20-trial blocks, three blocks under each of the two feedback conditions. On $40 \%$ of the trials under each condition, all Ss received information that they were the harmer, i.e., Light No. 1 lighted on S No. 1's panel, No. 2 on S 2's panel, etc. The victim following a sheet of instructions in front of her (but hidden from S's view), acted as if she had been shocked on $60 \%$ of the trials. Her response to alleged shock may best be described as a "startle" reaction. She jerked her hand up and jumped back slightly in her chair.

Each RT trial was initiated by a verbal "ready" signal given between .5 and $1.5 \mathrm{sec}$ before the onset of the RT stimulus light. After each trial, the victim pretended to record her judgment as to which $\mathrm{S}$ was fastest.

Following completion of all trials, Ss were debriefed. The debriefing was designed to determine whether Ss had discovered the true purpose of the experiment and to allay any concerns Ss might have about shocking the victim.

\section{RESULTS}

The data from 4 of the 32 Ss were omitted in the analyses reported here because of procedural irregularities arising during testing. Table 1 shows the effect of the visual contact and feedback conditions on RT for harming vs saving trials.

An analysis of variance performed indicated that the effects of harmer identification $(F=9.35, \quad d f=1 / 24$, $\mathrm{p}<.01$ ), response condition (saving vs harming trials) $(\mathrm{F}=13.59, \mathrm{df}=1 / 24$, $\mathrm{p}<.01$ ), and the interaction of these two variables $(\mathrm{F}=9.99, \mathrm{df}=1 / 24$, $p<.01)$ were all statistically reliable. In addition, a significant second-order interaction was obtained among visual contact, harmer identification, and response condition $(F=5.78$, $\mathrm{df}=1 / 24, p<.05$ ). As can be seen in the table, latencies on harming trials were much longer when Ss believed the victim knew the identity of the harmer. In addition, the longest harming RTs occurred when the victim not only could objectively identify her harmer, but also could see her. No on the data represented in the table differences occurred on saving trials as a function of these variables.

The debriefing sessions disclosed that 6 of the 28 Ss had some suspicions regarding the true purpose of the study, but these suspicions were retrospective and the data from these individuals did not differ systematically from that of the remaining Ss. None of the Ss voiced recognition of the fact that they were all the harmer at the same time or that the victim was not, in fact, painfully shocked.

\section{DISCUSSION}

None of the undergraduate women volunteering to take part in this study in exchange for course extra credit refused to participate when the potentially harmful consequences of the experimental task were defined for them. Moreover, none of the Ss refused to continue after observing what they reportedly believed to be the victim's honest reactions to the apparent shock. However, there was a general tendency among these Ss to resist the harm instruction as evidenced by the fact that response latencies reliably increased between saving and harming trials under all conditions of the study. The magnitude of this increase was heightened under conditions of harmer identification, demonstrating that being specifically identified as the potential harmer by the intended victim significantly reduces compliance with the harm instruction. The effect of harmer identification was enhanced under conditions of visual contact. Since the availability of facial pain cues (Baron, 1971), per se, failed to inhibit the aggressive response under the conditions of this study, it is plausible that the Visual Contact by Harmer Identification interaction resulted from the fact that visual contact further heightened the loss of felt anonymity occurring when the victim knew the identity of the potential harmer.

In conclusion, the results of this study suggest that compliance with orders to harm another individual is notably reduced when the harmer can be specifically identified by the victim. As proposed earlier (Bandura \& Walters, 1963; Milgram, 1965), the inhibitory influences of harmer identification may have its origins in the harmer's social learning history. That is, we may learn from prior social experience that aggressive activity against others is more apt to produce retaliatory punishment in cases where the victim can identify us as the aggressor relative to cases where our aggression can be conducted with some measure of anonymity.

\section{REFERENCES}

BANDURA, A., \& WALTERS, R. H. Social 
learning and personality development. New York: Rinehart \& Winston, 1963.

BARON, R. A. Magnitude of victim's pain cues and level of prior anger arousal as determinants of adult aggressive behavior. Journal of Personality \& Social Psychology, 1971, 17, 236-243.
MILGRAM, S. Some conditions of obedience to authority. Human Relations, 1965, 18, 57-75.

\section{CURRENT LITERATURE ON SOCIAL PROCESSES}

DAWSON, W. E. (University of Notre Dame, Notre Dame, Ind. 46556), \& BRINKER, R. P. Validation of ratio scales of opinion by multimodality matching. Perception \& Psychophysics, 1971, 9, 413-417.

FINE, B. J. (U.S. Army Research Institute of Environmental Medicine, Natick, Mass. 01760), \& SWEENEY, D. R. Comment on Schulz's and Strobach's "Catecholamine excretion as a function of personality." Psychonomic Science, 1971, 23, 410.

FITZGIBBONS, D. J. (Institute of Living, Hartford, Conn. 06102), \& GOLDBERGER, L. Task and social orientation: A study of field dependence, "arousal," and memory for incidental material. Perceptual \& Motor Skills, 1971, 32, 167-174.

GEEN, R. G. (University of Missouri, Columbia, Mo. 65201), \& STONNER, D. An extended apparatus for measuring aggression in humans. Behavior Research
Methods \& Instrumentation, 1971, 3, 197-198.

HATTON, D. E., SNORTUM, J. R. (Claremont Men's College, Claremont, Calif. 91711) \& OSKAMP, $S$. The effects of biasing information and dogmatism upon witness testimony. Psychonomic Science, 1971, 23, 425-427.

HINES, G. H. (Falcon Management Consultants Lld., 10 Dryden Chambers, 119 Oxford Street, London W1R, 1PA, England). Effectiveness of social and nonsocial reinforcers in a probability learning task. Psychonomic Science, 1971, 23, 411-413.

JASPERSE, C. S., \& VAN HEKKEN, M. J. Effect of nurturance on imitative behavior. Psychological Reports, 1971, 28, 201-202.

KELEMAN, K. S. (San Diego State College, San Diego, Calif. 92115). Note on looking time: Experimenter and instruction effects. Perception \& Psychophysics, 1971, 9, 224.

LIEBERT, D. E. (State University of
New York at Stony Brook, Stony Brook, N.Y. 11790), SWENSON, S. A., \& LIEBERT, R. M. Risk taken by the opponent and experience of subject as determinants of imitation in a competitive situation. Perceptual \& Motor Skills, 1971, $32,719-722$.

LINDSKOLD, S. (Ohio University, Athens, Ohio 45701), TEDESCHI, J. T., BONOMA, T. V., \& SCHLENKER, B. R. Reward power and bilateral communication in conflict resolution. Psychonomic Science, 1971, 23, 415-416.

THOMAS, M. (Boston University, Boston, Mass. 02215), \& LEVIN, J. Social constraint as a determinant of charitable behavior. Psychological Reports, 1971, 28, 14.

WEISS, R. F. (University of Oklahoma, Norman, Okla, 73069), \& MILLER, F. G. The drive theory of social facilitation. Psychological Review, 1971, 78, 44-57.

\section{CURRENT LITERATURE ON SOCIAL PROCESSES}

BANIKIOTES, P. G. (University of Notre Dame, Notre Dame, Ind. 46556), \& BANIKIOTES, F. G. Topic importance and proportion of item agreements as significant variables in interpersonal attraction. Psychonomic Science, 1971, 23, 296-297.

CLARK, R. D., III, \& CROCKETT, W. H. (University of Kansas, Lawrence, Kans. 66044). Subjects' initial positions, exposure to varying opinions, and the risky shift. Psychonomic Science, 1971, 23, 277-279.

GAEBELEIN, J, (Kent State University, Kent, Ohio 44240), \& TAYLOR, S. P. The effects of competition and attack on physical aggression. Psychonomic Science, 1971, 24, 65-67.

GEEN, R. G. (University of Missouri, Columbia, Mo. 65201). Social facilitation of long-term recall. Psychonomic Science, 1971, 24, 89-90.

KAPLAN, M. F. (Northern nlinois University, DeKalb, ㄲll. 60115). The determination of trait redundancy in personality impression formation. Psychonomic Science, 1971, 23, 280-282.

LA GAIPA, J. J. (University of
Windsor, Windsor, Ontario, Canada), \& WERNER, R. E. Effects of topic relevancy and attitude similarity on two measures of affiliation. Psychonomic Science, 1971, 24, 67-68.

LOMBARDO, J. P. (University of Oklahoma, Norman, Okla. 73069), WEISS, R. F., \& STICH, M. H. Interpersonal attraction as a function of amount of information supporting the subject's opinions. Psychonomic Science, 1971, 24, 79-80.

McKINNON, C. (Simon Fraser University, Burnaby, British Columbia, Canada), KOEPKE, J. E., \& APLAND, R. The effect of social reinforcement on the performance of 1-year-old children. Psychonomic Science, 1971, 23, 313-315.

McMILLEN, D. L. (Mississippi State University, State College, Miss. 39762), \& AUSTIN, J. B. Effect of positive feedback on compliance following transgression. Psychonomic Science, 1971, 24, 59-61.

METTEE, D. R. (Yale University, New Haven, Conn. 06510), TAYLOR, S. E., \& FISHER, S. The effect of being shunned upon the desire to affiliate. Psychonomic Science,
$1971,23,429-431$.

MYERS, D. G. (Hope College, Holland, Mich. 49423), WONG, D. W., \& MURDOCH, P. Discussion arguments, information about others' responses, and risky shift. Psychonomic Science, 1971, 24, 81.83.

POSAVAC, E. J. (Loyola University, Chicago, Ill. 60626), \& PASKO, S. $\mathrm{J}$. Interpersonal attraction and confidence of attraction ratings as a function of number of attitudes and attitude similarity. Psychonomic Science, 1971, 23, 433-435.

TESSER, A. (University of Georgia, Athens, Ga. 30601), \& BRODIE, M. A note on the evaluation of a "computer date." Psychonomic Science, 1971, 23, 300.

WALDMAN, D. M., \& BARON, R. A. (Purdue University, Lafayette, Ind. 47907). Aggression as a function of exposure and similarity to a nonaggressive model. Psychonomic Science, 1971, 23, 381-383.

YAKIMOVICH, D. (Center for the Study of Cognitive Processes, Wayne State University, Detroit, Mich. 48202), \& SALTZ, E. Helping behavior: The cry for help. Psychonomic Science, 1971, 23, 427-428. 